\title{
A FÉMKERESŐ MŰSZERES TEREPBEJÁRÁSOKTÓL A KÖZÖSSÉGI RÉGÉSZETIG BORSOD-ABAÚJ-ZEMPLÉN MEGYÉBEN
}

\section{BAKOS GÁBOR ${ }^{1}$}

Magyar Régészet 9. évf. (2020), 2. szám, pp. 65-70. doi: https://doi.org/10.36245/mr.2020.2.3

A múzeumbarát önkéntesek részvétele a régészetben egyre nagyobb jelentöséggel bir, bár hazánkban erre még nem született egységesen kidolgozott megoldás - megyénként változó a helyzet kezelése. Az elmúlt években különösen hangsúlyossá vált ez a kérdés a fémkeresö müszeres vagy a bármilyen más formában segíteni akaró civilek esetében. Bár egy-egy fémkeresős bevonása a régészek munkájába korábban sem volt példa nélküli, ám a nagyszabású, kiterjedt együttmüködési rendszerek még mindig újdonságnak számitanak. A miskolci Herman Ottó Múzeumban 2015 elején indultak meg az elsö kísérletek az általuk kidolgozott komplex modell gyakorlati alkalmazására. A kisérlet sikeresnek bizonyult, és egy folyamatosan fejlödö, rendkivül eredményes projektté vált. A program továbbra is formálódik és alkalmazkodik a lehetöségekhez, mindemellett a szakmai elvárások maximális betartására törekszik. Jelen cikk arra vállalkozik, hogy kétféle szempontból is bemutassa ezt a folyamot, hiszen a szerzöje - a múzeum régésztechnikusaként - részt vesz nemcsak a fémkeresős csoport tevékenységében, hanem a helyi program kidolgozásában és irányitásában, majd az ott szerzett tapasztalatok hasznositásában.

A közösségi régészet, a civilek részvétele a múzeumok munkájában sok tekintetben új jelenség hazánkban. Valójában ez nem újdonság, hiszen akár Angliából (RENFREw, 2000; BLAND, 2008) vagy Franciaországból (LECROERE, 2016) számos példa hozható fel az önkéntesek bevonására, az ott kialakult helyzet kezelésére. Magyarországon azonban csupán az elmúlt néhány évben kezdte bontogatni a szárnyait, és bár nem élünk nagy országban, a különböző régiókban eltérő az önkéntes régészeti munkák szakmai megítélése. Minden múzeum, amely valamilyen módon belekezdett ebbe, a saját igényeihez és lehetőségeihez mérten alakított ki egy rendszert, melynek célkitüzése az volt, hogy a szakma szigorú szabályait betartva összehozza az elhivatott civilek tömegét a múzeummal. Ez természetesen helyes dolog, hiszen a múzeumoknak maguknak kell meghatározniuk azokat az irányelveket, amelyek a lehetőségeikhez mérten a legmegfelelőbbek.

A civilek megjelenése minden fél számára előnyös helyzet, hiszen a régészettudomány visszajelzést kap arra, hogy az önkéntesek segítségével teheti gyorsabbá, gördülékenyebbé a munkáit. A segítők pedig közelebb kerülhetnek a múzeumok mindennapjaihoz; részt vállalhatnak a munkáikban; közös erővel, szakmai irányítás alatt tehetnek valamit a pusztuló régészeti örökségünk védelméért, a közös hagyatékunkért.

A különböző példák között említhetjük a Bíró Gyöngyvér és Rózsa Zoltán vezette orosházi összefogást (Bíró et al., 2017); Rácz Tibor Ákosnak a Pest megyében jól müködő és a megye határait is lassan átlépő kezdeményezését, amely napjainkban már egyesületi szinten funkcionál (RÁcz, 2019); valamint a Nemzeti Múzeum sikeres munkáit (MNM, 2020).

Miskolcon 2015 első negyedévében kezdtek kibontakozni a Herman Ottó Múzeumban azok a gondolatok, amelyek megalapozták a saját, egyéni elképzeléseimen alapuló, szakmai szempontú rendszerbe foglalt nagyszabású és komplex mintát. Szerencsés helyzet alakult ki, hiszen mind a múzeum, mind az intézményünk munkái iránt érdeklődők többsége nyitott volt a kétoldalú eszmecserére, amely lehetővé tette a közös projekt útnak indulását. A véletlennek tudható be, hogy éppen ebben az évben indult el az Európai Régészeti Tanács Amersfoort programja (EAC, 2015), amelynek az egyik kulcskérdése a régészet társadalomba történő beágyazása. A program célja az, hogy speciális témákra összpontosítva jövőképet állítson a régészeti örökségkezelésnek, lendületet adjon a régészeti örökség védelméről szóló Valletta Egyezménynek, és segítse a kulturális örökség társadalmi értékeivel foglalkozó Farói Egyezmény megvalósítását. A program válaszokat keres arra az igényre, miszerint az elméletet és a gyakorlatot a 21. századi európai régészettu- 
domány és a társadalom igényeihez mérten át kell alakítani (CoE \& EAC, 2019), ahogy arra már az örökségkezelésnek platformot biztosító Európai Régészeti Tanács (EAC) számos európai régészeti örökséggel foglalkozó konferenciája is rávilágított.

A magyarországi helyzet változását elősegítette az a jogszabályi változás, amely a fémkereső müszerek használatát változtatta meg jelentősen. 2014 decemberében módosította a parlament először radikálisabb formában a fémkereső használatához füződően a 2001. évi LXIV. törvényt (CsORBA, 2016). Így, amenynyiben az eszköz használata nem hivatás gyakorlásához szükséges, ahhoz hatósági engedély kell. A hatósági engedély megszerzéséhez nélkülözhetetlen feltételeket 2016-ban és 2018-ban módosították, amellyel lényegében tovább pontosították a 2014-ben megfogalmazottakat. A feltárási joggal rendelkező múzeumok gyüjtőterületükön belül nem csupán véleményezhették a beérkező kérelmekben szereplő kutatási terveket, hanem már a velük kötött együttmüködési megállapodás is az engedélyszerzés feltételévé vált.

Már az első megkeresések és beszélgetések pozitívak voltak, így alig vártuk, hogy a gyakorlatban is alkalmazhassuk az elképzeléseinket. Eleinte csak alig néhány intézmény kezdte meg ezt a tevékenységet kísérleti jelleggel. E mögött számos tényező állt, többek között el kellett oszlatni azt a tévhiteken alapuló bizalmatlanságot, amely a múzeumokkal szemben fogalmazódott meg civil fémkeresős körökben.

A miskolci program kidolgozásakor az volt a cél, hogy a múzeumot segíteni kívánó civilek egy csoportként, közösséget alkotva dolgozzanak együtt. Nem kész külföldi mintát vettünk át, hanem közösen, saját rendszer kidolgozására törekedtünk, amely a helyi adottságokhoz igazodva a legkedvezőbb müködés reményét vetítette elő, továbbá bizalmat ébreszthetett az akkor még ingadozó civilek között. Végül Szörényi Gábor András és Pusztai Tamás támogatásával létrejött az a modell, amely a mai napig szilárd alapja Borsod-Abaúj-Zemplén megye önkéntes programjának.

Az együttmüködést olyan sokrétü, több társadalmi réteget és közösséget megszólító, hosszú távú célkitüzésnek láttam, amely az elvégzett munkákon túl a helyi közösségekkel megosztott információkkal védi a régészeti lelöhelyeket. A közös munkamenetet igyekeztem úgy kialakítani, hogy a lehetö leghatékonyabban tudjon hasznosulni az a rengeteg energia, amit segítőink az önkéntes munkájukkal belefektetnek egy-egy alkalomba. Mindenképpen nagyon szervezett és szakmailag is stabil alapokon álló, megfelelően dokumentált rendszert képzeltem el, ahol nem fordulhat elő információvesztés.

A modell kialakításakor több szempontot is figyelembe vettünk: például azt, hogy az önkéntes csapatunk legnagyobb része a munkájából adódóan leginkább a hétvégéken ér rá. Az önkénteseink szakmai ismeretei is nagyon eltéröek voltak. A jelentkezőket egy rövid beszélgetést követően bátorítom, hogy vegyenek részt egy alkalmunkon, dolgozzanak együtt velünk. Itt minden esetben tájékoztatást kapnak az alapvető feladatokról, amelyen a gyakorlati munka közben igazítunk, finomítunk, és segítek elsajátítani a munka végzéséhez szükséges ismeretanyagot is. Ezzel a módszerrel személyre szabottabbá tehető a rendszerbe való beilleszkedés.

A folyamatos szakmai jelenlétnek több oka is van: minden segítő más és más eszközzel rendelkezik, amely különböző hatásfokkal vizsgálja a talajban rejlő fémtárgyakat. Ezenfelül nagyon sokat számít az is, hogy a tulajdonos mennyire ismeri a fémkereső müszerét, amellyel dolgozik. Így, ha egy adott területen több önkéntes vegyes tapasztalattal és vegyes minőségủ müszerrel kutat, akkor kiegészítik egymás munkáját. Emellett ellenőrizhető a kutatás és a dokumentáció minősége, és lehetőség nyílik arra, hogy a módszereiket finomítsák, tanulhassanak egymástól. Mindemellett a szakmai koordináció nagyon fontos a tárgyak leletkörülményeinek a megfigyeléséhez.

A fémkereső müszeres bejárások mindig olyan területeket vagy lelőhelyeket érintenek, ahol anyagi források vagy humán erőforrás hiányában nem tudtunk kutatásokat folytatni. Máskor viszont egy eleve ismert, de erös illegális bolygatásnak, rablásnak kitett lelöhelyet vagy annak körzetét vizsgáltuk. Ezekben az esetekben elsődleges cél a megelőzés, a lehető legtöbb emlék megmentése volt. Mindemellett a károk felmérése, dokumentálása, a szükséges lépések megtétele bizonyult még fontosnak, hogy a földben lévő régészeti korú tárgyak állaga tovább ne romolhasson. Ezenfelül tájékoztatjuk a kutatásunk iránt érdeklődőket, hogy milyen célból vagyunk jelen, és hogyan különböztethetik meg az illegálisan tevékenykedőket a múzeumok által képviselt fémkereső müszeres kutatóktól. 


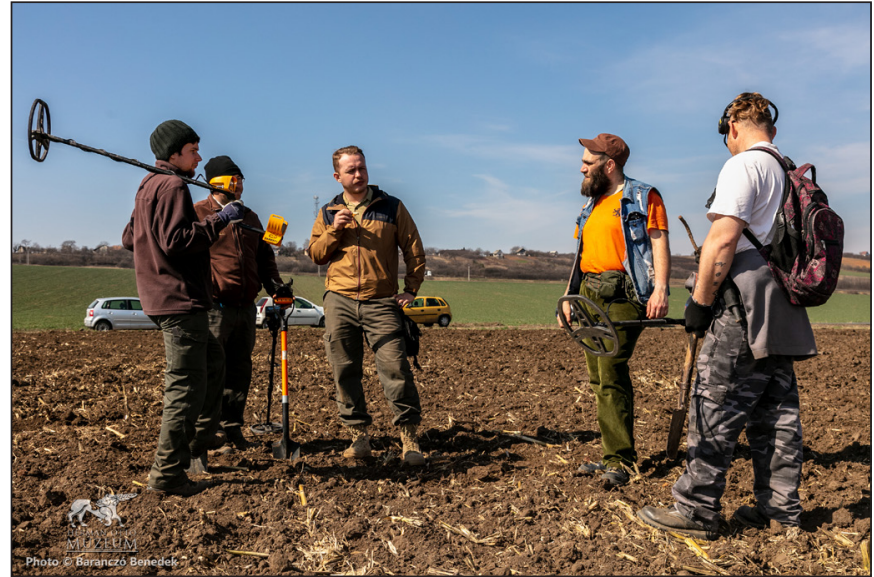

1. kép. Közös munka a terepen

A program elején el kellett döntenem, hogy a múzeum keretein belül megszervezett csoportos alkalmakra vagy az egyénileg, kis csoportokban tevékenykedő, némiképp független önkéntes civilek segítségére támaszkodom inkább. Elképzelésem szerint a közös munka a kulcsfontosságú elem (1. kép). A pontosság, a rendszeresség, azaz a szervezett, tematikus kutatások teszik komolylyá és hasznossá a munkát. Nem indítok tervezett terepbejárásokat, müszeres leletfelderítéseket azokon a lelöhelyeken, amelyek nincsenek közvetlen veszélynek kitéve, vagy az aktuális kutatásaink nem érintik őket.

Mint minden múzeumnak, a miskolcinak is problémát jelentene a nagy számban beérkező restaurálandó régészeti lelet, illetve a különböző, önállósult kutatók egyéni munkái után a megfelelő szakmai jelentés elkészítése. A dokumentációk határidőn belüli továbbítása az illetékes hatóságok felé, a restauráláshoz szükséges tetemes nagyságú források megteremtése is fontos kérdés. Mivel nem áll rendelkezésünkre korlátlan anyagi lehetőség, ezért a megelőző és célzott lelőhely-felderítési munka lehet csak hatékony és megfelelően kezelhető. Az előre tervezett alkalmak révén ellenőrizhető, kalkulálható mennyiségü lelet érkezik be a múzeumba (2. kép), amely e téren is kiszámíthatóbbá teszi a tevékenység esetleges anyagi vonzatát.

A dokumentálás már a terepen elkezdődik a helyszíni jegyzőkönyv vezetésével, amelyben minden információt részletesen felvezetünk: a résztvevők számát, az általuk használt fémkereső müszer típusát, a helyszín ismertetését, a környezeti tényezőket, a talaj és a terület állapotát, valamint annak bolygatottságát, veszélyeztetettségét is. Fontos a talaj nedvességtartalmának a feljegyzése, hiszen a fémkereső müszerek száraz, porhanyós, esetleg frissen lazított talajban kevésbé teljesítenek jól. A leletek előkerülési pontjait kézi GPS müszerrel rögzítjük a simítózáras tasakba helyezés előtt. A tasakon feltüntetjük a rögzített pont számát, a GPS müszer számát, netán a találó nevét és a lelöhely vagy a terület megnevezését. A leletkísérö lapok megírása már a kiterítés és a száradás után irodai körülmények között történik, mivel a tárgyak gyakran nedvesek, ami olvashatatlanná teszi a mellettük elhelyezett papírlapokat. A rögzített pontokhoz még társul egy egyénileg, a GPS müszer által jegyzett nyomvonal. Így a térinformatikai feldolgozás során értelmezhetővé válik, hogy a kisebb leletsürüségű vagy leletmentes területeken a kutató kevésbé alapos müszerhasználata vagy egyéb ok miatt nem talált leletet.

Az önkénteseinket nemcsak a terepi munkáinkba szerettük volna bevonni, hanem célunk volt az is, hogy megismerhessék intézményünk hétköznapi életének a múködését, és a múzeumi „vérkeringés”

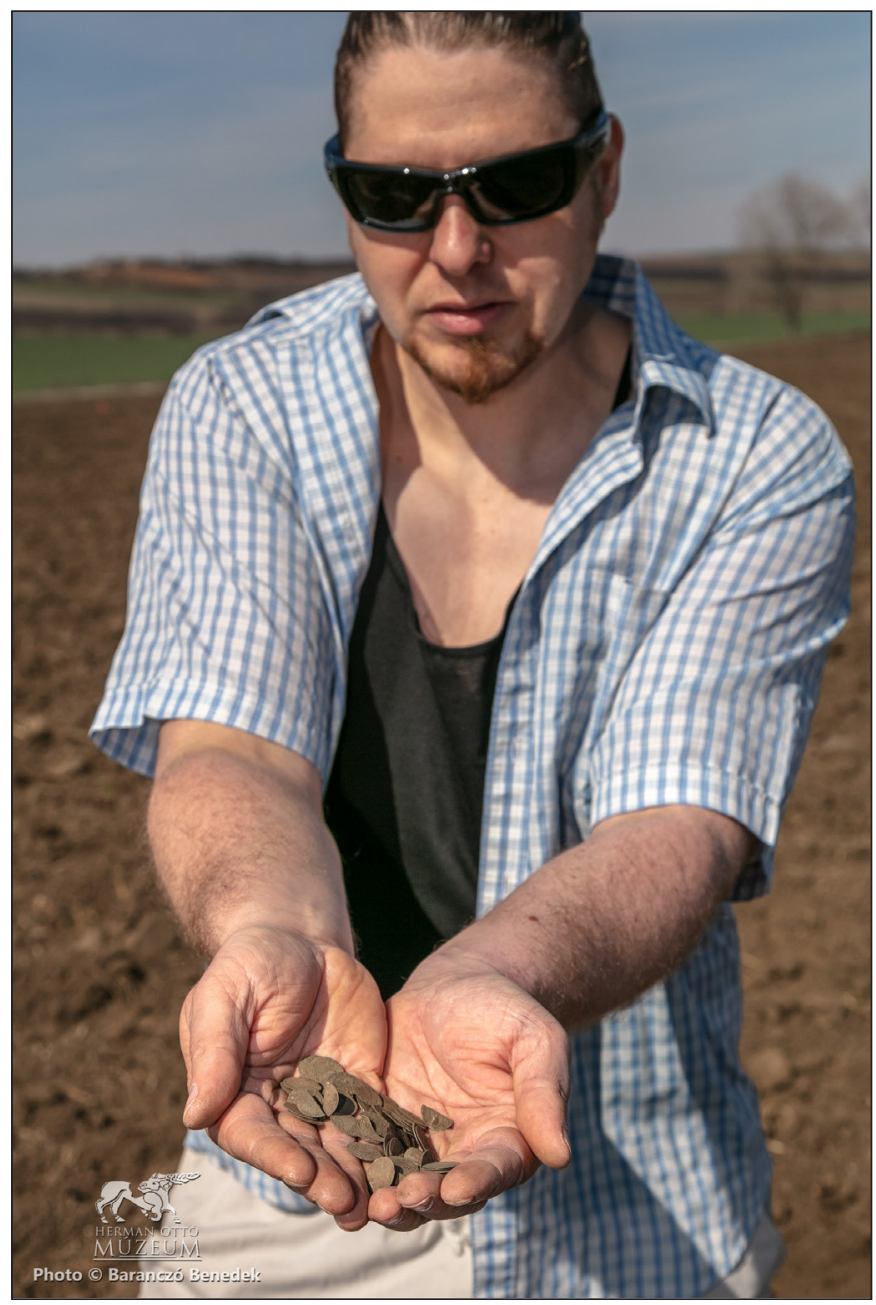

2. kép. Restaurálandó lelet 
részévé válhassanak. A terepi kutatási napokat az elökerült leletek irodai feldolgozása követi, ezáltal önkénteseink első kézből értesülhetnek azokról az információkról, amelyeket az adott kutatás során szereztünk, és amelyek már értelmezhetővé váltak a feldolgozás első lépcsőjében. Az önkéntesek szerepe azonban nem korlátozódik leletcsomagolásra és fémkeresős kutatásokra. Segítségükre már számtalanszor támaszkodtunk múzeumi rendezvényeinken, ásatásainkon, egyéb terepbejárási munkáinkon.

Kezdetben mindössze 2-3 fővel dolgoztunk együtt, amely könnyen kezelhetö, kevés koordinációs munkát igénylő feladat volt. A résztvevők száma folyamatosan nőtt, 2020-ra már elérte a több mint 60 föt. Ekkora létszámú csoportnál - föleg, ha kizárólag közös, a múzeum által előre megtervezett kutatási rendszerben gondolkodom továbbra is - nagy fokú szervezettség szükséges.

Emellett 2020 elejétől elindult a Herman Ottó Múzeum keretein belül egy oktatási program is, ahol a segítő szándékú önkéntesek nem csak a különbözö korok leleteivel és a korszakok fogalmával ismerkedhetnek meg. A régészeti korok megismerésén túl alapvető módszertani fogalmakkal és topográfiai alapismeretekkel bővíthetik a tudásukat, amelyet a későbbiekben a terepi munkák során is jó eséllyel hasznosíthatnak.

A közös értékeinkért folyó küzdelemben nem ritka a különböző helyről érkezett csapatok közös munkája sem. Ilyen többek között a mohácsi csatatér-kutatási projekt, amely évről évre egyre nagyobb sikereket ér el (SzABó et al., 2016). Hasonló elképzelésen alapul az a komplex, Laszlovszky József által vezetett kutatás, amely több intézmény és régió civil segítőit fogja össze. Megyénk területén az egyik fő feladatként a muhi csatatér feltérképezését tűzte ki célul, melynek természetesen a Herman Ottó Múzeum munkatársai és civil segítői is aktív részesei (LASzLovszky, 2017). Emellett lelkes segítőink aktív résztvevői az ELTE bronzkori erődöket, depókat vizsgáló programjának is, amelynek már korábbi, lenyügöző eredményei tökéletesen megmutatják a fémkereső műszerek hasznosságát a régészetben (V. SzABÓ, CzAJlik \& REMÉNYI, 2014).

\section{ÖSSZEGZÉS}

Fontos hangsúlyozni - ami sok fórumon és felületen is olvasható volt -, hogy a fémkereső müszeres kutatások, terepbejárások még nem összetett közösségi régészeti programok, de az érdeklődők leginkább ennek hatására lépnek kapcsolatba a múzeumokkal.

A közösségi régészeti tevékenységünk hosszabb távú célkitüzésének első lépése nemcsak azt jelenti, hogy a munkáinkba bevonjuk a részt vállaló civileket, hanem azt is, hogy a kutatásainkat, eredményeinket szélesebb körben tesszük ismertté. Fel kell hívjuk a földtulajdonosok és a települések lakóinak a figyelmét azokra a kulturális értékekre, amelyek kis odafigyeléssel megmenthetők és értelmezhetők. Ezekből az eredményekből pedig olyan egységes történet alkotható, amely hatékonyan kitágítja az ismereteinket az előttünk itt élt emberek hétköznapjairól. Ezzel nem csupán a települések történetét tesszük gazdagabbá, hanem új szemléletmódot is vihetünk a régészetbe. Azáltal, hogy a falvak, városok és az ott élő civilek érdekeltebbé válnak a saját múltjuk megörzésében, nagyobb szerepet kaphat az örökség védelme. E kezdeményezés kapcsán pedig a lakosok nagyobb eséllyel hívják fel a hatóságok, valamint a szakma figyelmét a saját örökségüknek is tekintett emlékek felszínre kerülésére, esetleges pusztulására.

Ennek egyik élen járó intézménye a miskolci Herman Ottó Múzeum, amely ma már több mint 60 fôs csapattal végzi a rendszeres kutatásainkat. Az együttmüködési kezdeményezések és a már meglévő rendszerek között még sajnos nincs szorosabb koordináció, mindenki a maga módján képzeli el annak jövőjét. Hosszú távon azonban elengedhetetlen, hogy a szakma egésze nyitottá váljon erre a kérdéskörre (V. SzABÓ, 2009), és mindenképpen szükséges egy egységes rendszer kidolgozása. Ez kétoldalú kommunikációval és közös protokoll kidolgozásával sokkal hatékonyabbá tehető, országos szintűvé emelhető.

Jelenleg az aktív együttműködések az ország különböző részein más-más szabályok szerint müködnek, és egyes megyékben ezek el sem indultak. A meglévőek között is komoly különbségek mutatkoznak, hiszen egyes múzeumok abszolút szabad kezet adnak a segítőknek. Emellett vannak, akik a különböző munkáikra, egyéb kutatásaikra hívják segítségül a civileket, akik ezt követően együtt dolgoznak a területen a régésszel.

A közösségi régészeti programoknak ezenfelül élesen el kell távolodniuk a tárgyközpontú szemlélettöl. A közös cél a kapacitáshiánnyal rendelkező múzeumok tehermentesítése és emellett egy komoly elhatáro- 
Bakos Gábor • A fémkeresö müszeres terepbejárásoktól a közösségi régészetig Borsod-Abaúj-Zemplén megyében

zás, amelynek eredményeképpen létrejöhetnek új publikációk, kiállítások, előadássorozatok. Ezek azok a mozzanatok, amelyek az embereket közelebb hozhatják a saját múltjuk jobb megismeréséhez, a régészeti emlékeik megóvásához.

Nagyon hosszú út elején tart az ügy, és még rengeteg a teendő, a megoldásra váró probléma. Az együttmüködések, a különböző egyéb programok, a szervezetek közötti folyamatos kapcsolattartás, információcsere, valamint a bizonyos helyeken jelenlévő komoly dokumentációs hiányosságok megoldása lehet az a cél, amellyel a következő időszakban kell foglalkoznunk.

\section{AJÁNLOTT IRODALOM}

Hudák, K. (2016). Egy államhatárokon átívelö társadalmi probléma - A régészeti célú fémkeresőzés múltja és jelene Magyarországon. Határrendészeti Tanulmányok 13 (1), 84-106.

Rácz, T. Á. (2017). Fémkeresősök a múzeum kötelékében. Közösségi régészeti modell építése Pest megyében. Magyar Régészet 6 (3) [2017 ösz], 1-7.

V. Szabó, G. (2009). Kincsek a föld alatt. Elrejtett bronzkori fémek nyomában. In Anders A., Szabó M. \& Raczky P. (szerk.), Régészeti dimenziók. Tanulmányok az ELTE BTK Régészettudományi Intézetének tudományos mühelyéböl. A 2008. évi Magyar Tudomány Ünnepe keretében elhangzott elöadások (pp. 123138). Budapest: ELTE BTK Régészettudományi Intézet.

V. Szabó, G. (2019). Bronzkori kincsek Magyarországon. Földbe rejtett fegyverek, ezsközök, ékszerek nyomában. Budapest: Archaeolingua.

\section{BiBLIOGRÁFIA}

Bíró, Gy. \& Rózsa, Z. (2017). Orosháza és vidéke 15-16. századi múltjáról. Utazó és időszaki kiállítás. Magyar Régészet 6 (2) [2017 nyár], 2-6.

Bland, R. F. (2008). The development and future of the Treasure Act and Portable Antiquities Scheme. In S. Thomas \& P. Stone (eds.), Metal Detecting and Archaeology (pp. 63-86). Woodbridge: The Boydell Press.

CoE [Council of Europe] \& EAC [Europae Archaeologiae Consilium] (2019). Strategy 21: Archaeological Heritage Management in Europe. https://rm.coe.int/strategy-21-archaeological-heritage-management-ineurope-in-less-than-/16808e9905 Letöltés: 2020. május 9.

EAC [Europae Archaeologiae Consilium] (2015). Amersfoort Agenda - Setting the agenda for the future of archaeological heritage management in Europe. https://f64366e3-8f7d-4b63-9edf-5000e2bef85b.filesusr. com/ugd/881a59 867792b3d3ae40cba005bd026f43a006.pdf Letöltés: 2020. május 9.

Csorba, Gy. (2016). Fémkereső müszerek. Infojegyzet 2016/20 [2016. május 5]. https://www.parlament. hu/documents/10181/595001/Infojegyzet_2016 20 femkeresok.pdf/2918a3d3-f10e-4d33-b03612d6fe3852fe Letöltés: 2020. január 25.

Laszlovszky, J. (2017). Fémkeresős kutatások Magyarországon. Új programok, eredmények. Magyar Régészet 6 (2) [2017 nyár], 1. 
Bakos Gábor • A fémkeresö müszeres terepbejárásoktól a közösségi régészetig Borsod-Abaúj-Zemplén megyében

Lecroere, T. (2016). "There Is None So Blind as Those Who Won't See": Metal Detecting and Archaeology in France. Open Archaeology 2, 182-193.

MNM [Magyar Nemzeti Múzeum] (2020). Közösségi Régészeti Program. https://www.facebook.com/ MNM-K\%C3\%B6z\%C3\%B6ss\%C3\%A9gi-R\%C3\%A9g\%C3\%A9szeti-Program-115976339811208/ Letöltés: 2020. május 9.

Rácz, T. Á. (2019). Közösségi régészet. Egy új kutatási eljárás születése. Múzeumcafé: a múzeumok magazinja 13 (4), 149-157.

Renfrew, C. (2000). Loot, Legitimacy and Ownership: The Ethical Crisis in Archaeology. London: Duckworth.

Szabó, M., Bertók, G., Gáti, Cs. \& Szajcsán, É. (2016). A mohácsi csatatér kutatása. Az első országos fémkeresős szakmai hétvége és tanulságai. Magyar Régészet 5 (2) [2016 nyár], 1-7.

V. Szabó, G. (2009). Kincsek a föld alatt. Elrejtett bronzkori fémek nyomában. In Anders A., Szabó M. \& Raczky P. (szerk.), Régészeti dimenziók. Tanulmányok az ELTE BTK Régészettudományi Intézetének tudományos mühelyéböl. A 2008. évi Magyar Tudomány Ünnepe keretében elhangzott elöadások (pp. 123138). Budapest: ELTE BTK Régészettudományi Intézet.

V. Szabó, G., Czajlik, Z. \& Reményi, L. (2017). Egy vaskori fegyveres konfliktus nyomai. Új topográfiai eredmények a dédestapolcsányi Verebce-tető kutatásában I. Magyar Régészet 3 (1) [2014 tavasz], 1-6. 